\title{
Methods for rearing larval decapod Crustacea
}

\author{
A. L. RicE ${ }^{1}$ and D. I. WILliamson ${ }^{2}$ \\ 1 British Museum (Natural History); London, Great Britain, \\ and \\ ${ }^{2}$ Marine Biological Station; Port Erin, Isle of Man, Great Britain
}

KURZFASSUNG: Methoden zur Zucht larvaler decapoder Crustaceen. Es werden Methoden zur Gewinnung und Zucht von Larven decapoder Crustaceen beschrieben. Die mit Erfolg eingesetzten Zuchteinrichtungen reichen von einfachen Glasschalen bis zu Geräten mit Wasserzirkulation, Belüftung, Ultraviolettbestrahlung und Temperaturkontrolle. Wert und Verfügbarkeit verschiedener Nahrungsobjekte sowie die Bedeutung von Temperatur, Salzgehalt, Licht und Wasserqualität werden erörtert. Methoden für die Massenzucht decapoder Crustacea werden kurz beschrieben und allgemeine Richtlinien in bezug auf die Wahl der Kultivierungsmethode und die Zielsetzung der Untersuchungen diskutiert.

\section{INTRODUCTION}

The metamorphosis of decapod crustaceans was first demonstrated by THOMPson in 1828 but was not accepted by the scientific community as the usual mode of development in the group until many years later. Thereafter, however, developmental studies progressed steadily, but during the 19 th century and well into the 20 th century, larvae were still described mostly from preserved material taken from field plankton. Identification of the species to which these larvae belonged was difficult, and many larvae, particularly those from poorly known deep waters, were described as distinct genera. With the development of marine biological laboratories and better facilities for maintaining living animals, zoologists began to hatch the early stages from ovigerous females and to maintain plankton-caught larvae until they moulted into the next stage, with the eventual aim of linking a series of such moults with an identifiable form. The efforts of such workers as LEBour (e.g. 1928) and GURNEY (e. g. 1942) were largely of this type and formed the basis for the great expansion of the interest shown in decapod development in recent years.

LEBOUR's considerable success in rearing larval Brachyura at Plymouth (England) in the 1920's forms an important exception, but this work was carried out in a laboratory in which oysters and other molluscs and polychaetes were being reared, and larvae of these species were readily available as food for the larval crabs. Apart from this, only a few species were reared successfully from the egg through metamorphosis in the early part of the century, and these were, as GURNEY (1942, p. 69) wrote "... chance successes, and failure was the general rule". In fact, it was not 
until the late 1950's that accounts of complete development of decapods under laboratory conditions began to enter the literature in numbers.

This review attempts to point out some of the major problems encountered in efforts to rear decapods in the past, and the ways in which at least some of them have been overcome.

These problems are mostly due to the fact that while the majority of adult decapods are bottom dwelling animals, the larval stages are almost all planktonic, so that metamorphosis involves not only major changes in morphology but also in habitat, behaviour and physiology. The primitive mode of development in the Crustacea was probably a gradual and continuous process of moulting and the addition of somites and limbs with no sudden changes between successive moults. Such a continuous development is seen in the present day Cephalocarida and in some Branchiopoda (SANDERS 1963), but in most crustacean groups the typical development includes a marked metamorphosis. The most complete metamorphosis is seen in the Copepoda which hatch as a nauplius, typified by antennal propulsion and the possession of only three pairs of functional appendages. After a number of moults with no major morphological changes the last nauplius stage metamorphoses abruptly into the first copepodid stage, which then develops gradually, through a number of moults, into the mature adult.

Within the Decapoda, the nauplius phase is retained only in the Euphausiacea and the Penaeidea, and in these groups it is followed by a second larval phase which corresponds to the first larval phase in the remaining decapods. A variety of names have been applied to these second phase larvae in the euphausiids and penaeids, but they should probably be referred to as zoeae since, like the zoea larvae of the more advanced decapods, they have natatory exopods on at least some of the thoracic appendages and they lack pleopods (WILLIAMson 1969). Except where the development is very much abbreviated, as for instance in many fresh-water or cold-water marine forms, both the naupliar and zoeal phases consist of more than one and sometimes many distinct stages separated by moults. In most decapods there follows yet a third stage, possessing functional pleopods for the first time but not yet a juvenile. This larval phase has also been given a variety of names but can be referred to as the megalopa phase. Throughout the Anomura and Brachyura this intermediate phase consists of a single stage, while in the Penaeidea, Euphausiacea and some Carideans it is less well marked and may consist of several stages.

The naupliar, zoeal and, to a lesser extent, the megalopa phases are all pelagic in habit and in most cases their ecological requirements differ quite markedly from those of their adult forms. This is most obvious in the case of crabs, particularly the terrestrial species, and the bottom living Anomura and Macrura. However, even where the adults are also pelagic they often live at very different depths from those frequented by the larvae. The problems of rearing decapod larvae are therefore largely the same as those encountered with rearing any planktonic creatures.

In their natural environment, decapod larvae do not normally encounter either wide ranges or sudden changes in such factors as salinity, temperature and oxygen concentration. Their food is suspended in the body of the water inhabited; they do not normally encounter solid surfaces, except those of other animals, and their mor- 
phology, frequently with delicate spines and setae, is unsuitable for contact with such surfaces where they may become damaged and pick up accumulated detritus and micro-organisms. One other problem, which is almost peculiar to the rearing of Arthropoda, is the moulting process which periodically increases the animals' susceptibility to damage and cannibalism.

Since all aspects of the planktonic habit cannot be reproduced artificially, rearing techniques must be mainly concerned with minimising the harmful effects of unavoidably unnatural conditions. Before reviewing the methods employed to do this, however, the basic problem of obtaining the larvae must be considered.

\section{OBTAINING LARVAE}

In some cases the decapod larvae used for rearing have been obtained live from the plankton. This procedure was commonly used before successful techniques for larval rearing were developed, the aim usually being to maintain each stage throughout at least one moult in the hope of linking together a successive series of plankton-caught larvae. A fairly high proportion of such larvae will moult once in captivity, without feeding; but further development usually depends on a suitable supply of food. The technique is still useful today in cases where adults are difficult to collect, or when unrecognized larvae are taken in planktological studies (RICE 1964), or where the larvae are notoriously difficult to rear, as in the case of the phyllosoma stages of the Palinuridae. If carried out parallel to laboratory rearing, it aids comparison between the development of the species in the sea and in captivity (e. g. Pike \& Williamson 1964 for Pandalus montagui LEaCH). In a few cases, eggs have also been obtained from the plankton (OMORI 1969). However, in most studies, where large numbers of larvae of known identity and in good condition are required, it is necessary to obtain them direct from the female parent.

In all decapod groups, except the Euphausiacea and the Penaeidea, the eggs are incubated by the female and are carried attached to specialised setae on the abdominal appendages, although there is no physiological connection between mother and embryo. The presence of eggs beneath the tail of a female is usually very obvious even where, as in crabs, the abdomen is normally held closely applied to the thoracic sternites, since the bulk of the egg mass prevents the female from closing the abdomen. The duration of embryonic development varies with the species and the environmental conditions, ranging from a few days to many months. The stage of development of the eggs can be determined roughly macroscopically. When first laid, the eggs are uniformly coloured, often bright orange, green, red or black; as development proceeds, the primary colours fade or become restricted to the unused yolk. Large areas of the developing embryo remain clear, but new pigmentation, particularly the intense black of the eyes, becomes apparent in the later stages. Eventually, usually within a few days of hatching, microscopic examination reveals limb movements, regular heart beat, and often a change in egg shape from spherical to ovoid.

The function of the adult female during the period when eggs are carried is to protect them from factors which would interfere with the normal development of the 
embryos. To this end the female spends a great deal of time cleaning the egg mass, and periodically paddles with the pleopods so that the water surrounding the eggs is replaced by fresh, oxygenated water. Because the female is so solicitous in her care of the egg mass, in most rearing work on decapods it has been found advantageous to leave the eggs in the female's care and allow them to hatch naturally.

This procedure does, however, have disadvantages in some cases. The adults of larger species may be difficult to keep alive in the laboratory because of space limitations or, as in the case of the very deep water species, they may be difficult to obtain in good condition in the field. Where the water containing the female cannot be replenished the larvae may hatch in a weakened condition. Where only a single ovigerous female is available and the optimum conditions of temperature and salinity are not known, a mistake in the choice of the environment may lead to the loss of all eggs. In artificial conditions of captivity, females will often discard or eat their eggs. Finally, experimental studies on the effects of different conditions on the embryonic development of genetically similar eggs are not possible if the whole egg mass is left on the female.

For these various reasons it is sometimes desirable to remove the eggs from the female prior to hatching and to keep them adequately aerated artificially. Good results have been obtained with a number of crab species by CostLow \& Bоокночт (1960), who divided the egg masses into groups of about 100 to 1000 eggs and incubated these groups separately in compartmented plastic boxes (see below) agitated on a variable speed shaker. Penicillin was used in an attempt to control the growth of harmful bacteria. Ciliate and fungal infections, once present, spread very rapidly amongst the eggs of a single group, hence culturing separated groups of eggs has the virtue of limiting the losses suffered if one or more of the groups does become infected.

In the Penaeidea and the Euphausiacea the eggs are shed into the water, and to obtain large numbers of eggs the females must spawn in captivity. Mature penaeid females in which spawning is imminent can be recognized by the size and colour of the gonad, usually visible through the exoskeleton. Spawning normally occurs at night and each female will produce many thousands of eggs, up to one million in some species (Hudinaga \& Miyamura 1962). The eggs sink to the bottom and can easily be siphoned off and transferred into fresh containers. The period of time between spawning and hatching in penaeids is relatively short (13-14 h in Penaeus japonicus BAtE, according to Hudinaga 1942); they therefore do not need much attention. Although batches of eggs of Penaeus duorarum BuRKENROAD were successfully hatched in finger bowls by EwALD (1965), gentle water movement produced by bubbling air through the medium or by a mechanical shaker, as mentioned above, would probably improve chances of success by preventing the clumping of the eggs on the floor of the rearing vessel. Compressed air is used to produce water movement in commercial rearing of $P$. japonicus in Japan (IDYLL 1965).

After they have hatched, decapod larvae are negatively geotactic and positively phototactic to unidirectional light. These responses can be exploited by using a combination of water currents and light to separate the larvae from the hatching chamber easily. 


\section{REARING THE LARVAE}

Most efforts to rear decapod larvae have been conducted on a very small scale, dealing with only a few hundreds to a few thousands of individuals at a time. Although the few large scale operations which have been undertaken represent in many respects simply normal experiments scaled up, they are rather special cases and will be considered later. The laboratory scale rearing techniques, while varying a great deal in detail, can broadly be divided into two types, the first involving little or no water movement or circulation, while in the other such water circulation forms a major feature.

\section{Rearing methods not involving water circulation}

The simplest technique, and undoubtedly the earliest one used, is to place the larvae, together with what is hoped to be suitable water, at a suitable temperature, with a suitable food, in some form of container and wait to see what happens. An almost endless variety of vessels has been used in this type of rearing. Understandably, items of normal laboratory and domestic glassware, and particularly finger bowls, have been favoured. Open vessels may need to be covered to prevent excessive evaporation.

One of the major difficulties with this type of rearing technique, particularly when dealing with hundreds or thousands of larvae resulting from laboratory hatching, is that of handling large numbers of individual containers, each holding only one or a few individuals. This problem has been largely overcome in recent years with the widespread use of compartmented transparent plastic boxes, first used by CosTLow \& Bookhout (1959) to rear the larvae of Callinectes sapidus RATHBUN at Duke University Marine Laboratory, Beaufort, North Carolina (U.S.A.), and subsequently used in a variety of laboratories. These commercially available boxes can be obtained with individual compartments in a variety of shapes and sizes, but the most commonly used type has 18 rectangular compartments to each box, each compartment having a volume of about $100 \mathrm{ml}$. The boxes are fitted with lids and can be conveniently stacked. The main advantages of the boxes are that they allow large numbers of larvae to be reared individually, but with different treatments, in a relatively small space.

Although some experiments have been conducted with larvae in compartmented boxes in which the water has been agitated on mechanical shakers, in most cases the water has been left static. In such conditions, oxygen depletion and fouling of the water by decomposing food or dead larvae are major hazards. This problem has usually been tackled by changing the water frequently, usually every second day, but sometimes at rather longer intervals. At these times, and whenever larvae are being moved, care must be taken so that the test animals do not become damaged; wide mouthed pipettes are essential.

Antibiotics have also been used to control bacterial growth in static water in which larvae have been reared. Various forms of penicillin, streptomycin, aureomycin and chloramphenicol have been employed, usually at dosages of between 50 and 
100 i.u./ml (Dobkin 1961, Reese \& Kinzie 1968, Williams 1968). Although there is good evidence that the use of antibiotics in the rearing of plaice may improve survival rates (SHELbourne 1963), no similar work seems to have been done on their effects on the survival of decapod larvae. Some preliminary results, however, suggest that antibiotics may even decrease survival rates in decapods (RICE et al. in press).

\section{Rearing methods involving water circulation}

Although the static water techniques outlined above have been used successfully in rearing many decapod species, there are some major disadvantages in these methods.

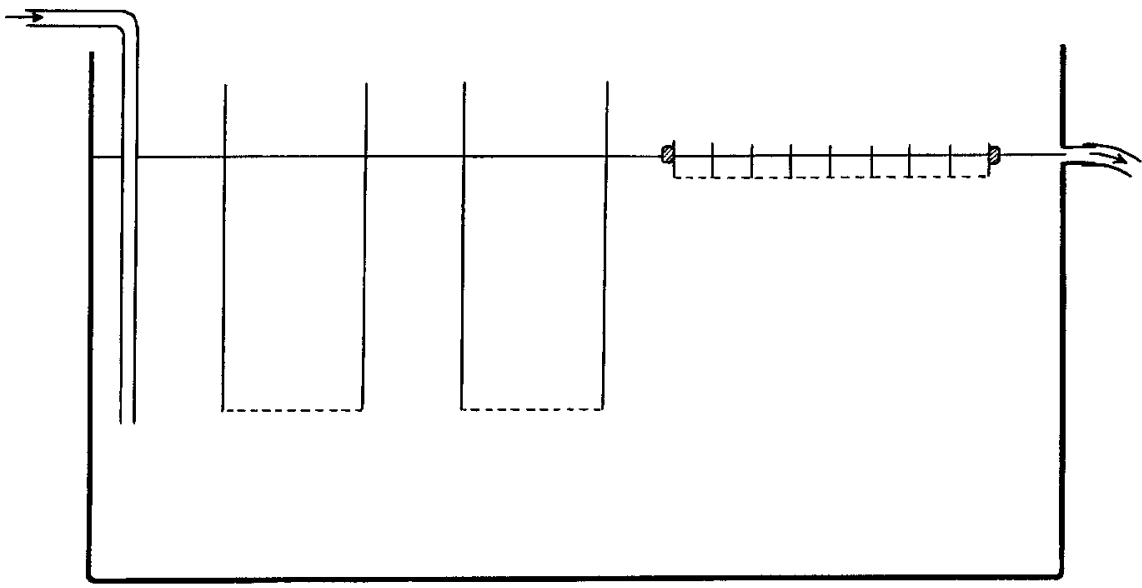

Fig. 1: Two perspex rearing cylinders and a floating compartmented box with mesh bottom in a tank of running sea water

In vessels containing still water, the larvae spend most of their time in contact with either the sides or the bottom; the smaller the vessel, the larger are these surfaces in relation to total water volume. Where several larvae are reared in a single vessel containing static water their phototactic responses are likely to concentrate them all in the region nearest to the light source, unless they are reared in total darkness or in diffuse light. Such concentrations may lead to increased cannibalism and even result in local oxygen depletion. The phototactic behaviour may also separate the larvae from their food, in extreme cases producing starvation in an abundance of unavailable nourishment. Planktonic larvae, whether they are filter feeders or particulate feeders, normally take the food particles from mid-water, and while many decapod larvae seem to need active animal prey, some feed on relatively non-motile plant material such as diatoms. In static water such non-motile food will settle to the bottom fairly quickly and again become unavailable to the larvae.

For various combinations of these reasons it is, therefore, often desirable to create water circulation within the rearing vessels; a number of methods have been used to achieve this. 
Where water of the desired salinity and temperature is abundantly available, an "open" circulatory system can be used. In such a system, fresh water is continually entering the culture vessels at one point and running to waste from another. If the water used is obtained directly from the sea, and not stored for any great length of time, an open circulation largely avoids the necessity for aeration or elaborate hygiene measures such as bacteriostatic treatment.

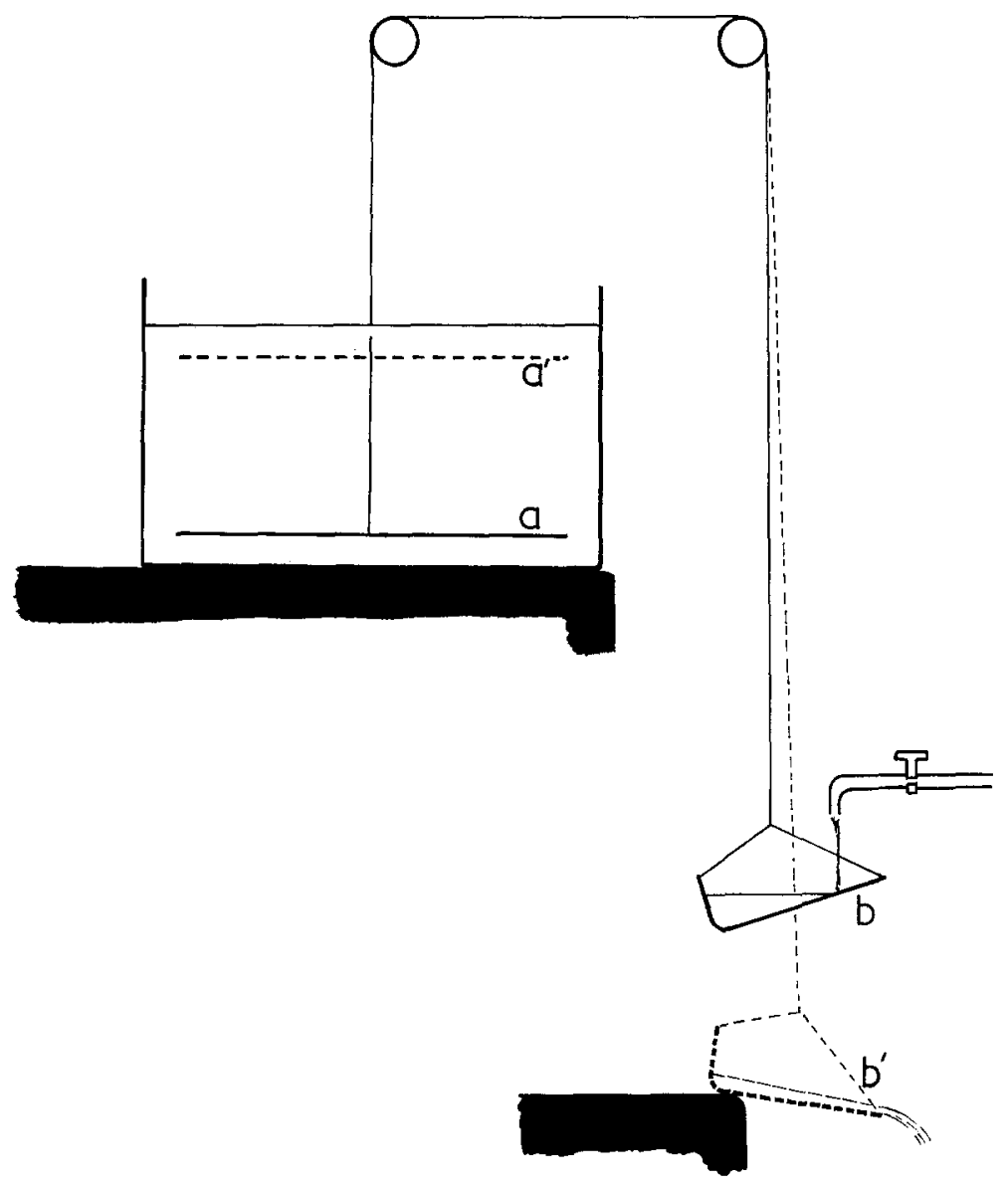

Fig. 2: Diagrammatic section of a plunger jar; $a, a^{\prime}$ glass plate, $b, b$ ' tipping bucket

A simple form of apparatus which has been succesfully used with an open circulation is the "perspex" cylinder, shown in Figure 1. Larvae are reared in a cylinder 10 to $15 \mathrm{~cm}$ in diameter and 15 to $30 \mathrm{~cm}$ long, suspended in a aquarium of running water. The upper end of the cylinder is above water level and the lower end is covered with a mesh of nylon or other material fine enough to retain the larvae. Smaller containers, for one or a few larvae, can be used in much the same way. Rarely, however, is water with the required physical characteristics available in such 
quantities and closed systems are more usual. Even with a closed system a through flow of water in the culture vessels can be achieved by using a circulation pump to lift the water into a header tank from where it eventually flows back into the culture vessel. The water can be heated, cooled, aerated, filtered or subjected to other treat-

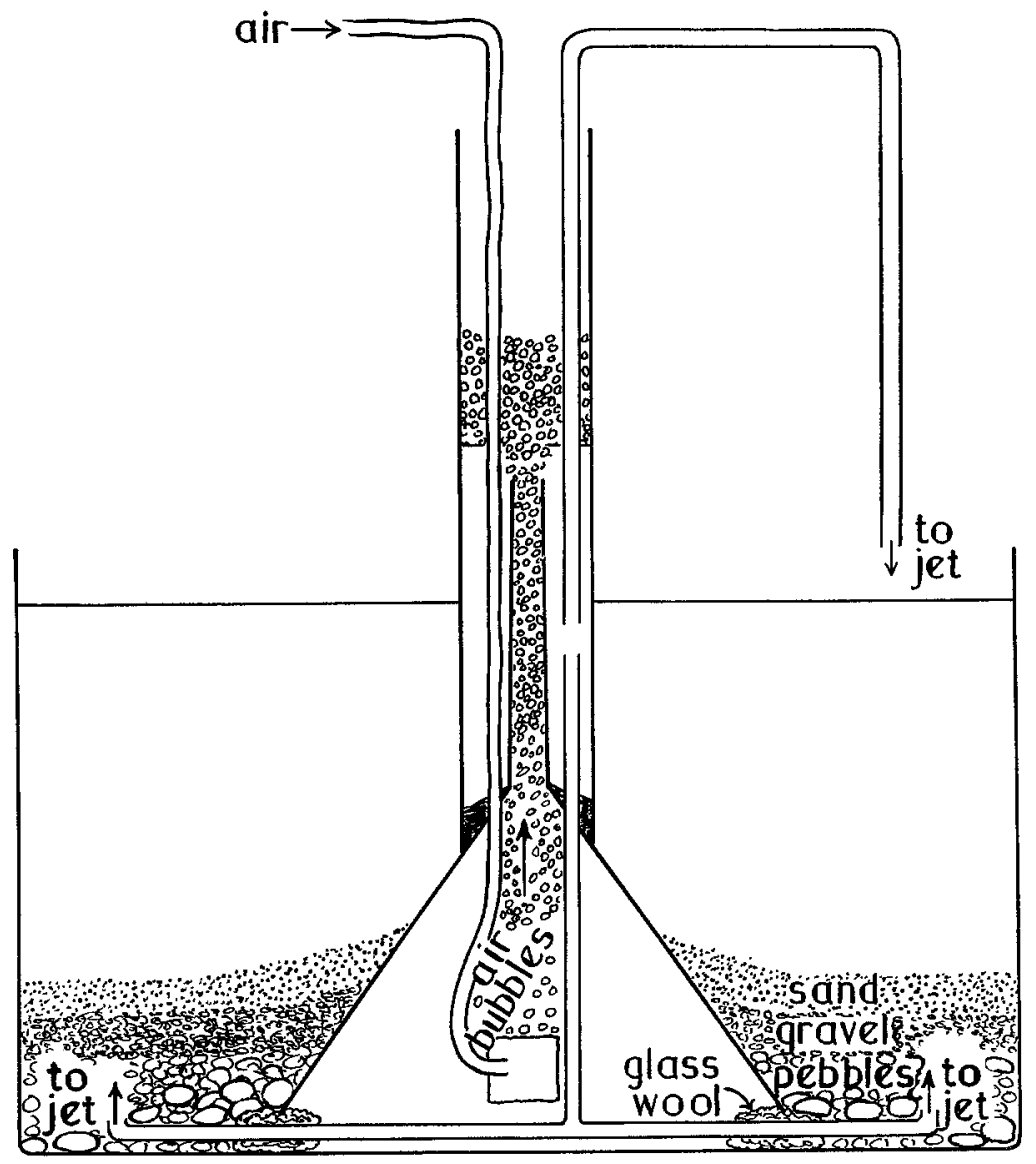

Fig. 3: Planktonkreisel. Viewed from above, all jets point clockwise (or counter-clockwise). The upper jet points horizontally and its tip is just above the surface of the water. The two (or more) lower jets incline slightly upwards (at about $15^{\circ}$ ) and project a little above the surface of the sand. (After GREVE 1968, modified)

ments during its circulation outside the culture vessels. Good examples of this type of circulation are those used for rearing plaice larvae by SHELbourne et al. (1963). One problem in through flow culture vessels is that the larvae must be separated in some way from the outgoing water stream. The larvae can be largely kept away from the region of the outlet by exploiting their phototaxis, but some form of filter is still necessary. Unless the filtration area is large relative to the water flow, the larvae may become caught on the filter and damaged. This problem was overcome by MoDin \& 
Cox (1967) by placing the larvae in floating compartmented boxes, the bottoms of which had been replaced by plastic mesh. This apparatus thus incorporates features of the compartmented box method and of the perspex cylinders mentioned above, together with a closed circulation system in which the water is sterilised with ultraviolet light, filtered and cooled.

Completely closed systems, in which the water never leaves the culture vessel but is agitated within it, avoid this filtration problem but have other disadvantages (see later). The classic plankton rearing technique is that using the "plunger-jar", in which the water within the vessel is kept in circulation by a plate, normally of glass, which is slowly raised and lowered, traditionally by a counterbalancing container which is periodically filled with water and emptied by siphoning or tipping (BROwNE 1897 and Fig. 2). Although the plunger-jar has been, and still is, a useful technique for maintaining the more robust planktonic organisms, the moving plate in the body of the water is liable to damage delicate creatures and the circulation which it provides tends to be very intermittent. Various systems of vanes and paddles moving in the water have also been used, but they all share with the plunger-jar the tendency to damage delicate larvae.

Water movement has also frequently been provided by bubbling air through the water column, simultaneously achieving at least some aeration. This technique produces extremely violent movement within the stream of bubbles with relatively little circulation in the remainder of the vessel. This type of agitation may be quite damaging to larvae, and there is considerable evidence that, it may decrease growth and survival rates (FORSTER \& WICKINS 1967).

In an attempt to avoid these problems of providing water circulation without violent local agitation the "planktonkreisel" has recently been developed at the Biologische Anstalt Helgoland (Greve 1968). In this system, the water in a circular culture vessel is filtered through a large area of gravel and sand on the bottom and then raised above the level of the general water surface by an air lift device which is separated from the cultured animals. The water returns to the culture vessel via a jet which opens close to the bottom and side of the vessel and provides a gentle circulation which tends to carry the animals away from the solid surfaces (Fig. 3). Modifications to the original design are the addition of glass-wool round the base of the funnel, which prevents sand entering the air-lift, and a surface jet, which prevents the formation of bacterial scums.

\section{ENVIRONMENTAL FACTORS}

The above discussion has been concerned mainly with the gross features of different rearing techniques. Since no single technique is best in all respects, the one adopted will depend on the facilities available and the aim of the rearing work. For instance, the systems employing water circulation are more suitable for mass rearing where large numbers of developing animals are required, whereas studies on intraspecific variations in morphology and moulting frequency require knowledge of individual developmental histories which can only be provided by rearing single individuals, 
normally in static water. Whichever method is used, however, other environmental factors must be considered.

The study of decapod larvae is still largely in a descriptive phase, and the morphology of definitely identified species has been the main concern of most papers published so far. Since such studies depend on at least some individuals surviving through metamorphosis, variations in the environmental conditions under which larvae have been reared have normally been introduced as an insurance against choosing an unfavourable single set of conditions and losing all the available material.

The factors most frequently investigated have been temperature, salinity and food, probably because these exert the most important influences on success or failure. Other factors, such as water-type and light, have received less attention.

\section{Temperature and salinity}

Each decapod species has absolute ranges of both salinity and temperature outside which development does not proceed. However, the two factors interact, so that towards the extremes of the tolerated range of either factor, the tolerated range of the other factor becomes reduced. Larvae of estuarine and brackish water species, such as the xanthid crab Rhitbropanopeus harrisii (GouLD), develop over a wide range of conditions of salinity $\left(2.5-40.0 \%\right.$ and temperature $\left(20^{\circ}-30^{\circ} \mathrm{C}\right)$ whereas other species, such as Sesarma cinereum (Bosc) and Panopeus berbstii MilneEDWARDS, develop only within a restricted range of salinity and temperature (COSTLow et al. 1960, 1962). Species which live as adults only in oceanic waters tend to be even less tolerant of salinity changes during their larval stages (CostLow \& BookHouT 1962). Within the tolerated range both mortality rates and duration of larval stages may vary considerably. There may be definite optimum salinity conditions above and below which mortalities and duration of development increase. In the case of temperature, in general, the duration of the stages increases as the temperature decreases; low temperatures may inhibit moulting without being actually lethal. Inhibition of moulting by high temperatures, which are not directly lethal, is probably less common; but there is some unpublished evidence that such inhibition may take place in Homarus gammarus (L.). The usual effect of supra-optimum temperatures is that the early stages are passed through more rapidly, but that mortality becomes so high that none of the larvae complete metamorphosis.

\section{The variety of foods used}

Decapod larvae generally appear to be particulate feeders and, although they have well developed compound eyes, it seems that they probably locate the food particles largely by touch (but see section on light). Accordingly a wide variety of small, motile animal food particles representing almost every phylum have been offered to decapod larvae. These include various polychaete larvae (Lebour 1928, REESE \& KINZIE 1968), barnacle nauplii (REED 1969), the larvae of various molluscs, 
including oysters, Teredo and mussels (LeBour 1928, REED 1969), and the eggs and larvae of various echinoderms (LeBour 1928, Costlow \& Bookhout 1962, WarNER 1968). Mixed plankton has been used by BROAD \& Hubschman (1963).

Non-living foods have also been used, including commercially available fish food, chopped mollusc flesh, fish flesh, fish liver, cow's liver, chopped raw beef and chopped boiled egg.

Although some of these foods have proved to be quite useful for some species they all have considerable disadvantages. It is not always possible to induce spawning in species used as food just when they are needed for rearing decapods, and nonmotile particles must be kept in suspension if they are to be available to pelagic larvae, any material which falls to the bottom is likely to be left there untouched and will eventually foul the water.

Perhaps the most important single advance in rearing decapods has therefore, been the widespread use of the nauplii of the brine shrimp, Artemia salina. As is well known, the commercially available resistant "eggs" of these crustaceans can be kept in the dry state for long periods and, if exposed to sea water, will hatch within a few hours to produce highly motile nauplius larvae. Despite the fact that they would never be encountered by the larvae of marine decapods under natural conditions, Artemia salina nauplii have proved to be an adequate food for the complete development of a large number of decapods representing almost all major sub-divisions of the order (see, for instance Tsurnamal 1963, Provenzano \& Rice 1964, Sin 1964, Rice \& Provenzano 1966, Boschi et al. 1968, Costlow \& Bookhout 1968a, 1968b, Diaz \& Ewald 1968, Herrnkind 1968, Reeve 1969). However, despite their very wide application, Artemia salina nauplii are not a suitable food for the larvae of all decapods and there is evidence that their nutritional value depends on their source (Forster \& WiCKINS 1967).

Some decapods cannot be reared on Artemia salina alone, particularly during the early stages. This is apparently true of some crabs (Williams 1968), penaeids (Hudinaga \& Mryamura 1962, Ewald 1965, Cook \& Murphy 1965), and some small carideans. A number of algal species have been used either to supplement or replace Artemia salina or other animal foods. These include species of the genera Ditylum, Isochrysis, Navicula, Nitzschia, Pbaeodactylum, Skeletonema, Chlorella, Dunaliella, Micromonas, Hemiselmis, Tetraselmis, and Prorocentrum. The same problem of non-availability to the crustacean larvae due to settling applies to most of these algae as to the non-living foods and the algal cells must therefore be kept in suspension if they are to be of maximum use to the larvae.

\section{Effects of food level on larval development}

At hatching, the larvae of decapods usually retain part of the embryonic yolk. In the Penaeidae such yolk reserve enables the naupliar stages to complete their development without feeding, food becoming necessary for the zoeal stages. In species with abbreviated development the yolk reserve may enable the larvae to metamorphose before they need to begin feeding, as in the case of the hippolytid shrimp Thor 
floridanus Kingsley (Dobkin 1968). In other species the yolk may enable the larvae to metamorphose without feeding under optimal temperature conditions, but the provision of food may make metamorphosis possible over a wider range of conditions. An example of this effect is seen in the hermit crab Paguristes sericeus MrnNEEDWARDS in which starved animals were able to reach the glaucothoe (megalopa) stage at $25^{\circ} \mathrm{C}$ but metamorphosis occurred at $20^{\circ} \mathrm{C}$ only in the presence of food (Rice \& Provenzano 1965).

In most decapods, however, food is essential if metamorphosis is to be completed. When food is in short supply metamorphosis may be seriously delayed. In the Brachyura, where there is little or no intraspecific variation in the number of larval stages passed through, this lengthening of the development is due to longer intermoult periods. Amongst the carideans, on the other hand, there is a great deal of variation in the number of zoeal stages which a single species may pass through. Here the effect of low feeding levels is both to lengthen the intermoult period and to decrease the rate of development, producing longer larval life with more stages than at high feeding levels (Broad 1957, ReEve 1969).

Despite the number of species which have now been reared, very little is known about the nutritional requirements of the larval stages. At the present time, Artemia salina tends to be the first food tried; if it turns out to be unsuitable, the choice of a better food is usually a matter of chance.

\section{Water type}

There is abundant evidence that natural sea waters differ in their suitability for rearing a variety of marine invertebrates, even when they cannot be distinguished by normal analytical techniques (WILSON 1958). Most of the evidence of biological differences between sea waters has come from work on larvae of polychaete worms, molluscs, and echinoderms; the work of Ewald (1965) on Penaeus duorarum, indicates that the same may be true of crustacean larvae.

Water may also be adversely affected by its treatment prior to its use for rearing larvae. The dangers of using water which has been in contact with copper and other metals has long been known, and the toxic effects of some types of glass and even stainless steel are also well documented. The tendency these days is to store and convey water only in vessels made of polyvinylchloride (PVC), polythene or glass fibre, but insufficient experimental work has yet been carried out to be certain that even these materials have no harmful effects.

$$
\text { Light }
$$

Very little experimental work has been carried out to determine the effect of light duration, intensity and wavelength on the development of decapod larvae. In many cases larvae have been reared in vessels exposed to the normal window lighting of the laboratory, with no attempt made to control it. Where temperature controlled boxes and refrigerators have been used successfully for larval rearing, the treatment 
of light has varied. In some cases light periods of 12 or $14 \mathrm{~h}$ in every $24 \mathrm{~h}$ have been provided (Costrow \& Bоoкноuт 1962, 1966, 1968a, b, 1969, Costlow et al. 1966), while in others the larvae have been kept in total darkness except for the relatively short periods during which they have been examined each day or two (Provenzano \& Rice 1964, Rice \& Provenzano 1966). Since metamorphosis has occurred successfully in all of these situations it is apparent that, at least for some species, light is not necessary for the normal feeding and development of the larvae.

Nevertheless, the fact that decapod larvae - along with most other planktonic animals - undertake extensive diurnal vertical migrations largely in response to the changing illumination of their natural habitat suggests that light is of considerable importance. There is some support for this in the report by ForsTER \& WICKINS (1967) that under similar light intensities the metamorphosis of the palaemonid Palaemon serratus was delayed by red light, while survival was slightly improved by blue light, when compared with the results obtained in white light.

\section{LARGE-SCALE METHODS}

The earliest attempts to rear decapods on a large scale were devoted to the lobster, and in the years between 1880 and 1920 there was a great deal of activity on both sides of the Atlantic, particularly in Norway, Canada and in New England. Virtually all of this work was government aided, with the aim of increasing the naturally occurring stocks by supplementing them with artificially hatched lobsters. In the early days the larvae were released into the sea very soon after hatching, but it was soon realised that the chances of ultimate survival would be greatly improved by rearing the animals through the very vulnerable larval stages. A variety of largescale rearing methods were tried including an elaborate complex floating laboratory of the Rhode Island Commission of Inland Fisheries, at Wickford, Rhode Island (U.S.A.). This consisted of a series of rafts beneath which were suspended large $\left(10^{\prime} \times 10^{\prime} \times 4^{\prime}\right.$ deep $)$ wooden rearing "cars", fitted with wire screen windows allowing water exchange and two-bladed horizontal paddles to produce a water circulation within the cars. This water movement was essential to prevent the lobster fry congregating in large groups and to cut down cannibalism. Each car was stocked with up to 20,000 first stage fry and survivals to the fourth stage of up to $42 \%$ were obtained (MEAD 1908).

Norwegian interest in lobster culture began with G. M. DANNEvig who hatched lobster larvae in 1883. Successive DANNEvigs have continued this type of work with government support to the present day. In recent Norwegian practice at Flødevigen (DANNEvig 1962), the larvae were reared in batches of about 8,000 to 10,000 in each tank, with a strong water current to "whisk the larvae about a bit" and cut down cannibalism.

Although a good many people have shown an interest in long term rearing of lobsters from the egg to marketable size, the length of time involved together with the almost unavoidable losses due to disease and cannibalism over such a period make such a project economically untenable. 
The much shorter life cycle of some of the prawns, particularly the warm water species, makes the possibility of long term rearing of these species much more attractive and there has been considerable interest in the subject in recent years. The undoubted leader in this field is Dr. M. Huninaga who has succeeded in rearing the Japanese prawn Penaeus japonicus from egg to marketable size within 6 to 10 months. Eggs are obtained from gravid females captured at sea and kept in tanks until spawning. The larvae hatch after 13 to $14 \mathrm{~h}$ at $26^{\circ}$ to $29^{\circ} \mathrm{C}$, and each tank (capacity about 240 1) is initially stocked with about 400,000 larvae. During the first $36 \mathrm{~h}$ of life the nauplius moults five times but does not feed. At the sixth moult the nauplius changes to the first of the zoeal stages and at this time the young prawns begin to feed. During the zoeal phase the prawns are fed the diatom Skeletonema costatum at first, gradually changing to a more carnivorous diet with oyster eggs and larvae, copepods, brine shrimp nauplii and molluscan eggs as the zoeae grow. There are 6 zoeal stages and the total development from egg to megalopa takes about 7 days; survival rates up to this stage amount to 20 to $80 \%$. The history of rearing $P$. japonicus in Japan and the methods now employed are described by Hudinaga (in press).

Penaeids are also reared on a large scale, though not yet commercially, in the United States. Penaeus setiferus (L.), Penaeus aztecus Ives, Xiphopenaeus kroyeri (HELLER) and Trachypenaeus similis (SMITH) have been reared successfully at the U.S. Fish and Wildlife Laboratory at Galveston. Here the gravid female prawns are placed in 250 gallon circular polythene tanks until they spawn; thereafter they are removed and the water is circulated through a small oyster shell filter to remove harmful metabolites released by the female at the time of spawning. Each tank is stocked with about 50,000 larvae and the water is gently aerated through air stones hung around the side of the tank. Early zoeal stages are fed phytoplankton, mainly Skeletonema costatum, Thalassosura sp., and Cyclotella sp.; later zoeal stages receive also brine shrimps. The duration of larval stages ranges from 8 to 12 days; a survival rate of $70 \%$ to juvenile stages is considered normal.

Research on the large-scale culture of various Palaemonidae is proceeding in several countries, but the only species which is at the present reared on a commercial scale is Macrobrachium rosenbergii (DE MAN), for which successful methods have been developed in Malaya by LING (in press). This species passes through eight or more zoeal stages within 30 to 45 days at $26^{\circ}$ to $28^{\circ} \mathrm{C}$; these larvae are reared in batches of about 60,000 in aerated brackish water in cement troughs and are fed on mixed zooplankton, Artemia salina nauplii, fish eggs, and prepared foods such as egg custard and fish balls. On an average, about $17 \%$ of the hatched larvae reach the juvenile stages. The species breeds throughout the year in Malaya. Preliminary studies into the possibility of intensive cultivation of Macrobrachium rosenbergii have also been conducted in the U.K. (WICKINS 1969).

\section{CONCLUSIONS}

Most of the successful rearing of decapod Crustacea has been carried out in very simple apparatus, keeping the larvae as far as possible in water similar to that in 
which they or their parents were collected and avoiding rapid changes of temperature. Unsuccessful attempts at larval rearing have usually been attributed to lack of suitable food. The biggest gaps in the knowledge of larvae from a taxonomic point of view concern oceanic and deep-water species, but there is as yet no reason to suppose that the methods used for shallow-water species should not again be applicable, although in many cases the work may have to take place at sea. While drawing attention to the lack of knowledge of oceanic larvae, it must also be noted that the larvae of vast numbers of shallow-water species still remain unknown, and their descriptions should make many minor and some major contributions to the systematics of the Decapoda. In addition to larval studies from a taxonomic point of view, studies on the physiology, behaviour and experimental ecology of decapod larvae are likely to increase steadily, and important advances in these fields may be expected to follow in the next decade.

The choice of rearing apparatus must be governed largely by the aim in view and by any known difficulties presented by the species. Small bowls in which the water is changed regularly are adequate for mud taxonomic work. Perspex cylinders in a tank of running water are also useful for rearing fairly large numbers of larvae, and they have advantages in that the work of changing the water is eliminated and the considerable bulk of water involved tends to smooth out any changes in temperature. The planktonkreisel, as yet largely untried for decapod rearing, may prove particularly useful when a suitable food for the larvae has not been discovered. The apparatus is known to be suitable for a wide range of planktonic species, and offers the possibility of presenting decapod larvae with mixed plankton from which they may select their food, while observations on food selection and feeding behaviour should also be possible. Obviously, large omnivorous predators, such as ctenophores, should be removed from the mixed plankton before it is added to the plankton$\mathrm{kreisel}$, unless the behaviour of the larvae to such species is of special interest.

In any studies on the number of larval stages or the frequency of moulting it is a great advantage to be able to keep larvae as single individuals, and here the compartmented box, with one larva per compartment, is to be recommended. In experimental studies, larvae in different compartments, even within the same box, may be given different chemical environments or different foods, and different boxes may be kept at different temperatures or in different lighting conditions.

There is great need for working out new rearing techniques for Decapoda and for critical comparisons of results obtained with different techniques. The proportion of species which cannot be reared in captivity for lack of a suitable method is very small. The only group of larger size for which repeated rearing attempts have met with only limited success is the family Palinuridae; the phyllosoma larvae of this group appear to be specialised feeders, but there is little information on their natural food and no fully adequate laboratory food has yet been discovered. 


\section{SUMMARY}

1. The main methods which have been used for obtaining and rearing decapod larvae are reviewed. These methods range from very simple ones involving little or no control over the environmental conditions, to quite complex techniques with control over such factors as temperature, salinity, and light.

2. The difficulties encountered in rearing decapod larvae are largely the same as those met with in rearing any other planktonic organisms. Although failure to provide suitable food is probably the most important single factor responsible for the failure of many attempts in the past, other features of the rearing conditions may also be critical. In this context the effects of temperature, salinity, light and water type on larval development are briefly discussed.

3. No single rearing technique is suitable for all species and all situations. The choice of technique in any particular case will, therefore, depend largely on the aim in view, whether it be taxonomic, physiological, behavioural or commercial.

\section{LITERATURE CITED}

Boschi, E. E., Goldstern, B. \& Scelzo, M. A., 1968. Metamorfosis del crustaceo Blepharipoda doelloi Schmitr de las aguas de la provincia de Buenos Aires (Decapoda, Anomura, Albuneidae). Physis, B. Aires 27, 291-311.

BROAD, A. C., 1957. The relationship between diet and larval development of Palaemonetes. Biol. Bull. mar. biol. Lab., Woods Hole 112, 162-170.

- \& Hubschman, J. H., 1963. Larval development of Palaemonetes kadiakensis Rathiun in the laboratory. Trans. Am. microsc. Soc. 82, 185-197.

Browne, E. T., 1897. On keeping medusae alive in an aquarium. J. mar. biol. Ass. U.K. 5, $176-180$.

Cook, H. L. \& Murphy, M. A., 1965. Early developmental stages of the rock shrimp, Sicyonia brevirostris Strmpson, reared in the laboratory. Tulane Stud. Zool. 12, 109-127.

Costlow, J. D. \& Bookнout, C. G., 1959. The larval development of Callinectes sapidus Rathbun reared in the laboratory. Biol. Bull. mar. biol. Lab., Woods Hole 116, 373-396.

- - 1960. A method for developing Brachyuran eggs in vitro. Limnol. Oceanogr. 5, 212-215.

- - 1962. The larval development of Sesarma reticulatum SAY reared in the laboratory. Crustaceana 4, 281-294.

- - 1966. Larval development of the crab Hexapanopeus angustifrons. Chesapeake Sci. 7 , 148-156.

- - 1968a. Larval development of the crab, Leptodius agassizii A. Milne-Edwards, in the laboratory (Brachyura, Xanthidae). Crustaceana, Suppl. 2, 203-213.

- 1968b. The complete larval development of the land crab, Cardisoma guanbumi LATREILLE, in the laboratory (Brachyura, Gecarcinidae). Crustaceana, Suppl. 2, 259-270.

- - \& MONroE, R., 1960. The effect of salinity and temperature on larval development of Sesarma cinereum (Bosc) reared in the laboratory. Biol. Bull. mar. biol. Lab., Woods Hole 118, $183-202$.

- $\ldots$ 1962. Salinity and temperature effects on the larval development of the crab, Panopeus herbstii MrrNe-EDwards, reared in the laboratory. Physiol. Zoöl. 35, 79-93.

- -1966 . Studies on the larval development of the crab, Rbitbropanopeus harrisii (GouLD). I. The effect of salinity and temperature on larval development. Physiol. Zoöl. 39, 81-100.

Dannevig, G., 1962. Hummeren og hummerfisket. Fauna, Oslo 15, 197-204. 
Diaz, H. \& Ewald, J. J., 1968. A comparison of the larval development of Metasesarma rubripes (RATHBUN) and Sesarma ricordi H. Milne-Edwards (Brachyura, Grapsidae), reared under laboratory conditions. Crustaceana, Suppl. 2, 225-248.

Doвкіn, S., 1961. Early developmental stages of pink shrimp, Penaeus duorarum from Florida waters. Fishery Bull. Fish. Wildl. Serv. U.S. 61, 321-349.

- 1968. The larval development of a species of Thor (Caridea, Hippolytidae) from South Florida, U.S.A. Crustaceana, Suppl. 2, 1-18.

Ewald, J. J., 1965. The laboratory rearing of pink shrimp, Penaeus duorarum Burkenroad. Bull. mar. Sci. 15, 436-449.

Forster, J. R. M. \& Wickins, J. F., 1967. Experiments in the culture of the prawn Palaemon serratus (Pennant). In: C.M.-I.C.E.S., Fisheries Improvement Committee, 1967/E. 13.

Greve, W., 1968. The "Planktonkreisel", a new device for culturing zooplankton. Mar. Biol. 1, 201-203.

Gurney, R., 1942. Larvae of decapod crustacea. Monogr. Ray Soc. 129, 1-306.

HerRnkind, W. F., 1968. The breeding of Uca pugilator (Bosc) and mass rearing of the larvae with comments on the behaviour of the larval and early crab stages (Brachyura, Ocypodidae). Crustaceana, Suppl. 2, 214-224.

Hudinaga, M., 1942. Reproduction, development and rearing of Penaeus japonicus Bate. Jap. J. Zool. 10, 305-393.

- 1969. Kuruma shrimp (Penaeus japonicus) cultivation in Japan. In: Proceedings of the World Scientific Conference on The Biology and Culture of Shrimps and Prawns, Mexico, June 1967. FAO Fish. Rep. 57 (3), 811-832.

- \& Mryamura, M., 1962. Breeding of the "Kuruma Prawn" (Penaens japonicus Bate). J. oceanogr. Soc. Japan 20th Anniversary Vol., 694-706.

IDyLl, C. P., 1965. Shrimp nursery. Natn. geogr. Mag. 127, 636-659.

Lebour, M. V., 1928. The larval stages of the Plymouth Brachyura. Proc. zool. Soc. Lond. 1928, $473-560$.

LING, S. W., 1969. Methods of rearing and culturing Macrobrachium rosenbergii (DE MAN). In: Proceedings of The World Scientific Conference on The Biology and Culture of Shrimps and Prawns, Mexico, June 1967. FAO Fish. Rep. 57 (3), 607-619.

MEAD, A. D., 1908. A method of lobster culture. Bull. Bur. Fish., Wash. 28, 219-240.

Modin, J. C. \& Cox, K. W., 1967. Post-embryonic development of laboratory-reared ocean shrimp, Pandalus jordani Rathbun. Crustaceana 13, 197-219.

Omori, M., 1969. The biology of a sergestid shrimp Sergestes lucens Hansen. Bull. Ocean. Res. Inst. Univ. Tokyo 4, 1-83.

Pike, R. B. \& Widtiamson, D. I., 1964. The larvae of some species of Pandalidae (Decapoda). Crustaceana 6, 265-284.

Provenzano, A. J. \& Rice, A. L., 1964. The larval stages of Pagurus marshi Benedict (Decapoda, Anomura) reared in the laboratory. Crustaceana 7, 217-235.

REED, P. H., 1969. Culture methods and effects of temperature and salinity on survival and growth of Dungeness crab (Cancer magister) larvae in the laboratory. J. Fish. Res. Bd Can. 26, 389-397.

ReEse, E. S. \& Kinzie, R. A., 1968. The larval development of the coconut or robber crab Birgus latro (L.) in the laboratory (Anomura, Paguridea). Crustaceana, Suppl. 2, 117-144.

ReEVE, M. R., 1969. Growth, metamorphosis and energy conversion in the larvae of the prawn, Palaemon serratus. J. mar. biol. Ass. U.K. 49, 77-96.

Rice, A. L., 1964. The metamorphosis of a species of Homola (Crustacea, Decapoda, Dromiacea). Bull. mar. Sci. Gulf Caribb. 14, 221-238.

- \& Provenzano, A. J., 1965. The zoeal stages and the glaucothöe of Paguristes sericeus. A. Milne-Edwards (Anomura, Diogenidae). Crustaceana 8, 239-254.

- - 1966. The larval development of the West Indian sponge crab Dromidia antillensis (Decapoda, Dromiidae). J. Zool., Lond. 149, 297-319.

- Ingle, R. W. \& Allen, E., 1970. The larval development of the sponge crab, Dromia personata (L.) (Crustacea, Decapoda, Dromiidae), reared in the laboratory. Vie Milieu (in press). 
SAnders, H. L., 1963. Significance of the Cephalocarida. In: Phylogeny and evolution of crustacea. Ed. by H. B. Whittington \& W. D. I. Rolfe, Cambridge, Mass. Mus. of Comp. Zool, 163-179.

Shelbourne, J. E., 1963. A marine fish-rearing experiment using antibiotics. Nature, Lond. $198,74$.

- Riley, J. D. \& Thacker, G. T., 1963. Marine fish culture in Britain. I. Plaice rearing in closed circulation at Lowestof, 1957-1960. J. Cons. perm. int. Explor. Mer 28, 50-69.

SrN, ONG KAH, 1964. The early developmental stages of Scylla serrata Forskål (Crustacea, Portunidae), reared in the laboratory. Proc. Indo-Pacif. Fish. Coun. 11, 135-146.

THompson, J. V., 1828. Zoological researches, and illustrations; or natural history of nondescript or imperfectly known animals, in a series of memoirs. Vol. 1 (1), 1-19.

Tsurnamal, M., 1963. Larval development of the prawn Palaemon elegans Ratekke (Crustacea, Decapoda) from the coast of Israel. Israel J. Zool. 12, 117-141.

WARNER, G. F., 1968. The larval development of the mangrove tree crab, Aratus pisonii (H. MiLne-Edwards) reared in the laboratory (Brachyura, Grapsidae). Crustaceana, Suppl. 2, 249-258.

WICKINs, J. F., 1969. Preliminary experiments in the culture of the prawn Pandalus platyceros (BRANDT) and the giant prawn Macrobrachitum rosenbergii (DE MAN). In: C.M.-I.C.E.S., Fishery Improvement Committee, 1969/E. 2.

Williams, B. G., 1968. Laboratory rearing of the larval stages of Carcinus maenas (L.) (Crustacea, Decapoda). J. nat. Hist. 2, 121-126.

Williamson, D. I., 1969. Names of larvae in the Decapoda and Euphausiacea. Crustaceana 16, 210-213.

Wirson, D. P., 1958. Some problems in larval ecology related to the localized distribution of bottom animals. In: Perspectives in marine biology. Ed. by A. A. Buzzati-Traverso. Berkeley, Univ. of Calif. Press, 87-103.

First author's address: Dr. A. L. Rrce

British Museum (Natural History)

Cromwell Road

London S.W. 7, Great Britain 